\title{
A Spy for the Empire: Julian S. Corbett at the Quebec Tercentenary, 1908
}

\section{Donald M. Schurman}

\begin{abstract}
Julian S. Corbett, l'historien naval britannique renommé, a assisté aux célébrations du tercentenaire de Québec en 1908. Corbett avait écrit un des meilleurs récits du siège du Québec de 1759, mais en 1908 il servait de " espion» pour le directeur d'intelligence navale de l'Amirauté. Les ressources disponibles pour la défense de la Grande-Bretagne étaient bien en demande et l'Amirauté cherchait de l'information sur l'aide que l'on pouvait attendre en provenance du Canada. Corbett a obtenu des avis divergents au Québec, mais a conclu que le Canada pourrait aider si la Grande-Bretagne était diplomatique dans son approche. Corbett a également vu de ses propres yeux comment les célébrations ont tenté de faire la soudure entre les différentes vues anglo- et franco-canadienne sur l'histoire. Dans une nouvelle introduction à cet article, repris d'un livre publié en 1981, l'auteur fait remarquer que la dualité franco-et anglo-canadienne notée par Corbett lors des célébrations a été habilement traitée en 1999 par H.V. Nelles dans son livre L'art de la construction d'une nation.
\end{abstract}

\section{Author's introduction to the reprint}

This record of one man's participation in the Quebec celebrations of 1908 adds to the almost mystical account of them that Professor H. V. Nelles has given us in his splendid book, The Art of Nation-Building: Pageantry and Spectacle at Quebec's Tercentary (Toronto: University of Toronto Press, 1999). High intelligence, keen observatory powers, combined with the enthusiasm of a tourist make Corbett's account of this affair interesting. The account, published by me in 1981, missed Canadian focus and interest because it was hidden in a book on strategy and naval history published in England. When it was published the British naval publishing advisers suggested that the Canadian material was out of place, but because of Corbett's important connection with the events of 1759 I decided otherwise. As a Canadian I was intrigued with an event that saw, as Nelles has shown, two Canadian memorials, one to Champlain and one to Wolfe, unfolding as a supposed act of unification. Corbett responded to all this with interest, but

The Northern Mariner/le marin du nord, XIX No. 1, (January 2009), 43-56 
not as a disinterested party for he came to Quebec to report to the director of naval intelligence, Captain Edmond Slade (who was shortly to be promoted to rear-admiral), on what Canadian defence support the Imperial authorities could expect in the future. Corbett was a sort of naval spy. He was a distinguished naval writer and his book, England in the Seven Years' War would have been of interest to most at the Tercentenary, if often for different reasons. He met a few native Canadians, such as the mayor of Toronto, William Lyon Mackenzie King, Robert Borden, and Sir Wilfred Laurier. But since he was a sort of semi-spy he found it easier to get information about Canada from those Imperial gadflies and appointees who buzzed around every situation: the governor general, Lord Roberts, and British Army officers seconded for duty with the Canadian Militia were prepared to talk about how support could be extracted from Canada. The locals were not forthcoming with such information, not surprisingly. Of course Corbett never talked to Quebeckers about the strategic prognostics. (The other people he did not speak to about strategy, as far as one knows, were the officers of the Royal Navy warships who transported him and the other distinguished British visitors to Quebec.)

So, at base, Corbett was part of a pressure-cooker designed to extract funds/support from Canadians. He eventually reported to the director of naval intelligence that a slow and easy approach was the best way of handling Canadians, in practical terms not very far from Sir John Fisher's view that Canadians were not likely to be helpful.

It all seems trite and the shadow boxers were left shadow boxing. But a game was to be played out in the long run which was not to be slow and easy. There was a huge battle going on in England. It was a battle for access to public funds between the Army and the Navy, between Fisher and his Army opponents, and attitudes towards the Canadian armed forces were bound to reflect attitudes in Britain. Money depended on political support for either the Army or Navy. Corbett and Slade tried for a middle course, arguing that cooperation with the Army to develop amphibious activity would give Fisher most of what he wanted, but Fisher violently disagreed.

In 1908 the Army was still relatively small and the Navy bursting with dreadnoughts. No sooner had the Great War begun, however, than the Army in England under Kitchener's auspices (and in Canada under Sam Hughes) forged ahead in activity and demands on national resources. It was not Canadian sailors who were front and centre, but soldiers, 60,000 of whom made as the saying went "the supreme sacrifice." It turned out that Canada was emphatically a part of the military-naval thing called Imperial Defence.

December 2008, Kingston, Ontario. 


\section{[Reprint from Donald M. Shurman, Julian S. Corbett, 1854-1922: Historian of British Maritime Policy from Drake to Jellicoe. $]^{1}$}

Apart from holidays with his family in the country Corbett's life during these years was closely bound in by naval history, lectures to the War College, and antiquarian pursuits. The outstanding exception to this routine occurred in 1908, when he was able to attend the commemoration of the founding of Quebec City. Distinguished British guests, of whom the most important were the Prince of Wales and Lord Roberts, and including such lesser figures as Halford MacKinder the geographer, and Corbett, were to take part. They were transported there by units of the Royal Navy. It was a month's holiday of an exciting and different kind.

His selection to make the trip was owing, in part, to the fact that his latest history, England and the Seven Years' War, had devoted a good deal of space to the 1759 siege and capture of the city, so that he could be considered an expert on one aspect of the military and naval life of Quebec City. Another, and more important reason was that the Director of Naval Intelligence wanted him to investigate aspects of Canadian defence planning. That is to say, Slade wanted Corbett to determine, quietly, what military (especially naval) contribution Canada was prepared to make to the defence of the Empire as a whole. The mission was not a straightforward one. Corbett was given no right to negotiate with responsible Canadian politicians; that is, he was simply to gather what information he could without either alarming Canadians or revealing British attitudes - since the attitude of the Admiralty especially was by no means clear or consistent. Put simply, The First Sea Lord and the rest of the Admiralty Board were not at one on questions of Imperial Defence.

Sir John Fisher had no confidence in Dominion assistance. His doctrine was clear: the Royal Navy would control and dispose of its own. Even with regard to Australia, where there was some disposition to contribute financing to naval defence Fisher was against stationing ships in Australian waters. This was not very surprising, but the First Sea Lord was even against sending ships there on visits. ${ }^{2}$ With regard to Canada his views were even more forthright. "He says he knows the Canadian," wrote Slade, "and that they are an unpatriotic grasping people who only stick to us for the good that they can get out of us, and that we ought to do nothing whatsoever for them. ... His policy would be an absolutely fatal one for this country to follow and it is sincerely to be hoped that the Cabinet will not have it."

1 Editor's note: This text was originally published as chapter 6, "Quebec, 1908," in Donald M. Schurman, Julian S. Corbett, 1854-1922: Historian of British Maritime Policy from Drake to Jellicoe, Royal Historical Society Studies in History Series No. 26 (London, 1981), 99-112. It is reprinted with the kind permission of the Royal Historical Society.

2 Slade Diary 7.V.08. Fisher refused to send ships to join with those of the United States on a special visit there. See also Slade Diary 1.VII.08 which described Admiralty as unfavourable to having an Australian naval force established and expressed preference for a subsidy. National Maritime Museum, Greenwich, England (NMM).

3 NMM Slade Diary 9.V.08. 
This situation was complicated. It was being canvassed by the Committee of Imperial Defence (C.I.D.) where the view held that a naval threat to the coastline of the United States would serve to divert a wartime American threat to the Canadian Frontier. ${ }^{4}$ Fisher, who distrusted the C.I.D. almost as much as he did Canada, hoped to get the discussion of Canadian defence transferred from the C.I.D. to the Cabinet. He was supported in this view by John Morley, the Secretary of the State for India. But Sir Edward Grey, the Foreign Secretary, wanted the problems thrashed out in the C.I.D. before a Cabinet decision was taken. ${ }^{5}$ In spite of Fisher's opposition, ${ }^{6}$ Slade managed to convey to the C.I.D. his views that two divisions, one in Newfoundland and one in Jamaica, would "hold" the Americans. ${ }^{7}$ Corbett had been consulted by Slade and agreed that the two divisions would contain all that the "Canadian militia could not handle." 8 Meanwhile Haldane, the Secretary of State for War, wished the C.I.D. to work up a vast design to milk the Dominions of both men and money for ships. ${ }^{9}$ It was this sort of thing to which Morley objected, holding that such a subject, being political, was a Cabinet matter. It was a great muddle. (Incidentally. Corbett informed Slade that, constitutionally speaking, Morley was right, but that was no reason for the various Secretaries of State not getting expert advice from knowledgeable soldiers and sailors, and the right place to get that advice was at the C.I.D. $)^{10}$

Whatever one may think of the procedural question it is clear that Sir John held the view that Canada was both indefensible and niggardly in defence matters. Slade was sending Corbett to check up on these views. He was to discover whether there was any Canadian disposition to "take the defence of her frontier in hand - and [towards] starting a naval militia. She must make herself sufficiently strong on the Lakes to prevent [the] U.S. from rushing them. It must be done very carefully and slowly without ostentation and parade, but if it is efficiently carried out she [Canada] will add enormously to the strength of the Empire as a whole and assist the navy quite as much or more than if she went in for Battleships and Cruisers." 11 No doubt Corbett went out to Canada disposed to Slade's viewpoint.

The Quebec Naval Force was under the command of Admiral Curzon-Howe, who was very attentive to Corbett, partly because Admiral W. Henderson had written commending him, and partly by virtue of the historian's own reputation. ${ }^{12}$ The Squadron comprised two divisions: the battleships Exmouth, Duncan and the cruiser Arrogant in the

\footnotetext{
$4 \quad$ NMM Slade Diary 10.V.08.

$5 \quad$ NMM Slade Diary 14.V.08.

$6 \quad$ NMM Slade Diary 12.V.08.

7 Corbett Diary 15.V.08.

$8 \quad$ Ibid.

$9 \quad$ NMM Slade Diary 15.V.08.

10 This point, perhaps, has some bearing on Fisher's reluctance to speak at War Council meetings in 1915. It was a point that was not properly settled before World War 1 - if, indeed, it was generally understood.

11 NMM Slade Diary 1.VII.08.

12 Corbett Diary 4.VII.08; [Corbett papers, privately held] CP/B10
} 
first, and Albermarle and Russell with the cruiser Venus in the second. On board the Russell with Corbett was the distinguished geographer Halford J. MacKinder, whom Corbett already knew as a fellow member of the Coefficients dining club, and who was "no end of a swell" in Tariff Reform circles ashore and "a very nice fellow." ${ }^{13}$ Rear Admiral John Jellicoe was in the Albermarle and impressed Corbett and everyone else as "perhaps the cleverest young flag officer in the service." 14

Corbett went as the guest of the Captain of the Russell, and he had been given the "State" cabin. As an honorary member of the Ward Room he was made to feel quite at home, and he reciprocated the friendly kindness by lecturing the officers on the taking of Quebec, while MacKinder talked to the same audience on Canadian geography. ${ }^{15}$ As a further gesture of appreciation, Corbett presented the Ward Room with a drawing of the Battle of Solebay ${ }^{16}$

Moving through the shimmering seas the ships practised evolutions as they approached the Straits of Belleisle. Corbett was especially pleased with the effect as the two squadrons passed a giant glinting iceberg and manoeuvred so that nature's great ice palace passed close by the Russell in the centre of an echelon formation. He found the enthusiasm of the sailors infectious, and it was generally fading evening light above that forced him below where he improved what extracurricular time was left by writing enthusiastic reports to his wife and reading Sir Gilbert Parker's book In Old Quebec.

The North Atlantic in July was colder than he had anticipated, but the weather warmed up as they entered the Gulf, and finally, on the 18th they took on the pilot at Father Point and began the ascent of the stately river. Every landmark had an historical connection for him. He was lucky in nature as well, for swift changes between mist, clear sun and thunderstorms as they sailed gave life to those kaleidoscopic visual marvels for which Champlain's river is famous. They went through the Traverse at the east end of the Island of Orleans at seventeen and a half knots on a carrying seven and a half knot tide providing a great contrast to Saunders's stake-boated procession in 1759, and literally shot in to the Basin with the old city rising behind it. Occasions like these bring out all a battleship captain's latent destroyerman's instincts. The big ships fairly surged up under the citadel and dropped their gigantic anchors with a flourish under the walls of the historic bastion.

One small mishap marred the beginnings. The fleet coal-carrier ran aground, a greater mishap than Saunders had suffered in wartime years ago, and this delayed the coaling for a few days. This was a matter of some annoyance since both the dressing and the entertainment of guests on board had to wait on the completion of that filthy task. But there was much to be seen and done on shore. In particular, Corbett eagerly walked and sailed over the old campaigning ground. The water investigations were carried out with the help and interest of Admiral Kingsmill, who placed a boat at Corbett's disposal on

13 Corbett to Edith Corbett (ERC) 4.VII.08; CP/B10.

14 Corbett to E.R.C. S.VII.08; CP/B10.

15 Corbett Diary 12, 13.VIl.08.

16 Corbett Diary 7.V1II.08. 
several occasions, and in this way he visited both the Montmorency end of the battle area and the water route above the city where the final dispositions for the 1759 landings had been facilitated by the ships of Admiral Holmes's division. Corbett's first comments, beyond the fact that he made visits, were few. But he did mention that at Montmorency, the water in the river was now low enough that it was currently a much less formidable obstacle than it had once been. With regard to the land side of the campaign, he was helped and interested by Colonel William Wood, "a nice refined manly scholar - a real historian and a real scholar," ${ }^{17}$ who walked over much of the field with Corbett, Jellicoe and Burrows, the son of the late Chichele Professor of War at Oxford: Corbett was particularly interested in Wolfe's Cove, and remarked that "it does not look much from the fleet but when you get close you see the cliff is all loose shale - that is like a slope of sliding slate chips most difficult to get a foothold in." 18

The ships had dropped anchor on Wednesday, 15 July, and although there was a continual round of sightseeing and entertainment, in which His Majesty's ships took their full share after the coaling, the official programme itself began with the arrival of His Royal Highness, the Prince of Wales, a week later. In the meantime, Corbett was presented to the Governor General. He also talked to that most eminent guest, his old opponent over the invasion affair, Lord Roberts of Kandahar. During a trip up the river, the historian and the famous soldier talked, not unnaturally, of the strategy and methods of combined operations. Corbett asked him about the command of such expeditions, and found that "he takes [the] German view but I put its difficulties which worried him but did not alter his opinion." "The old soldier pointed out that during the Afghan campaign he had insisted on and secured political as well as military control of affairs. Also, Corbett sought and obtained advice on "many points on Wolfe's tactics that puzzled me" from Roberts.

After the politicians had arrived and the appropriate welcome had been given, and speeches made, the celebrations moved ahead swiftly. Thursday saw the arrival of a replica of Champlain's ship, followed by a fireworks display from Levis at night. The next day was very hot and featured a Grand Review of Canadian militia forces on the Plains of Abraham, which Corbett thought very badly arranged - the only thing that impressed him was the physique of the men. He turned his back on the State Ball in the evening to commune with his far away wife by letter. ${ }^{20}$ But he was watching the next day as the Prince reviewed the fleet. It is noticeable that both the French and the United States Governments had fleet representatives there and yet Corbett wrote nothing about their part in the naval show except that on one occasion the Russell entertained officers from the Admiral Geupratte who became more congenial with the passage of time and wine, but who presented, according to Corbett, a most unseamanlike appearance. He noted that one officer wore a pince-nez which seemed incongruous in a sea warrior. ${ }^{21}$

17 Corbett to E.R.C. 20.VII.08; CP/B/10.

18 Corbett to E.R.C. 15.VII.08; CP B/10.

19 Corbett Diary 21.VII.08

20 Corbett to E.R.C. 24.VII.08; CP B/10.

21 Ibid. 
The next day Corbett's enthusiasm for the sea had to take second place to his admiration for the historical pageant executed on the Plains of Abraham. It is worth repeating in detail here:

After lunch it was a case of top hat and frock coat again for the gala performance of the Pageant. I had an official seat again and saw it splendidly. My dear, I wish I could give you a faint idea of what it was like. To say it was the most beautiful thing I ever saw, except your dear self, seems but a faint indication of the elation it aroused in us all. Though the Prince had a great dinner in the evening at 8.15 and the pageant did not begin till 5.00 nothing could induce him to leave till it was all over and our Admiral went away ferocious because he had to get away to dress in his ship for the state dinner. I was invited too but H.R.H. or no H.R.H. I simply could not leave till the end. Winchester ${ }^{22}$ was far surpassed. Not that the Pageant itself was much better, but the mise en scène was beyond description ....

You must imagine first the grand stand on the grassy plains of Abraham where the battle was fought - some Two to Three Hundred feet above the river. The broad open piece of grassy plain was in front of it about as big as the fields between Imber and the road. ${ }^{23}$ At the right front it sloped gradually to a wooded glen and beyond a glade stretched for half a mile until it was lost in the thickening woods. On the left and left front, the plain ended in bushes below which it falls abruptly to the river. So that the characters in the pageant would be concealed below the crest and emerge at the right moment as though coming up from the river where Wolfe landed. The background was broad still river with its cliffs on the other side and then the miles and miles of woodland dotted with villages stretching away to the dim blue of hills of the American frontier. Can you imagine what a setting it made in the evening sun; for it began at 5.00 and ended at 7.30 as the sun sank below the horizon bathing the last scenes in a flood of rosy light. There were between 3,000 and 4,000 performers, some hundreds of whom were real Indians who had begged to take part and they did it with vigour in their wild leather and feather costumes, fighting, war dancing and chanting. The first scene opens with a solitary Indian watching the river from beside his wigwam - then Jacques Cartier came climbing up the cliffs from the river attended by his crew and friendly Indians and he took possession of the country for Francis I. Then came his return to France and reception at Fontainbleau by Francis I the change of scene from the wilderness to the garden was very much applauded. Parties of blue jackets had been lent by the fleet. As Jacques Cartier disappeared below the crest they rushed heavy frames, garden vases, statuary etc. and in a minute the rough bushes were transformed into gorgeous Rhododendrums and the place given the look of a formal garden. Then at the high forest at the end of a glade half a mile away began to emerge from the trees the Royal hunting party, hundreds of gaily dressed 
men and women - and singing as the[y] came coming across the little valley - up again to the arena in loose groups, yet one informal procession just like a return from hunting to-day. With that lovely background of river and wilderness it was really a beautiful thing to see. So it went on as lit by the changing light of the half clouded evening as tho some skillful hand were playing the lime light. I cannot tell you all the scenes but they alternated with gorgeous court pageant in France and then simple counter-parts in the infant colony with Indians and trappers for lords and ladies. Then we had fights - Indian fights, but none between French and English. They dare not do that - besides the whole thing was meant . . . to heal old sores. So the last scene was the armies of Wolfe and Montcalm marching in shoulder to shoulder and doing a sort of trooping the colour to the English and French heroes of Canadian history on horseback in the centre and surrounded by the courts of Francois I and Henry IV and Louis XIII. Then when all was in order blue jackets formed behind all with the last glow of sunset at the back. They bore the arms of all the provinces and as the band played "O Canada" they released a little cloud of white doves. It gave us all a thrill down the back and we cheered and cheered again. ${ }^{24}$

The dinner Corbett attended that night he had originally thought to be a mere "consolation to the riff-raff of guests like myself who had not been to the other State dinners. But I found out to my joy it was the great function." They began at 9.00 and it was nearly midnight when they rose. Speech after speech pledged eternal peace between the English and the French, the solidarity of the Empire, and loyalty to the Crown. The pageant had generated tremendous enthusiasm that found voice at the dinner table. Englishmen found it a poignant moment when de Villiers, the Chief Justice of South Africa, "solemnly announced the message of loyalty from the Boors." It was, wrote Corbett accurately, "one long Imperial debauch."

That night before he went back on board, Corbett was introduced to the Prince of Wales, and had an opportunity to congratulate the happy Governor General. Long after he returned to Russell, the historian, with his geographer friend MacKinder, paced the deck under the St. Lawrence moon, and pondered the secrets of Empire, rocked in its Canadian cradle. $^{25}$

Aside from official functions and historical sight-seeing, Corbett was exposed, for the second time in his life, to the Canadian scene. What did he make of it? When he had first visited Canada in 1879, he had been enraptured by the scenic wonders of the Quebec-St. Lawrence area. In this scene, time brought no great changes. He fully appreciated the unique beauty of the area and once more responded to it. He had not met any people of importance, or indeed many people at all, on his first visit. This time he had a much greater opportunity. His response to it was a conditional one, and he remained, in a sense, sealed off from Canadian life. He obtained most of his information about the colony from his English contacts, and he listened with care to the views of the Governor

24 Corbett to E.R.C. 26.VII.08; CP B/10.

25 Ibid. Corbett left no record of the details of his conversations with MacKinder 
General, Earl Grey, who honoured him with confidences, and to the views of General Lake $^{26}$ and Admiral Kingsmill. All of these men were inclined to refer to the native born Canadians as "they" and this applied with even greater force to the French speaking Canadians. He found in Colonel Wood, the historian, a less segregated figure, but their common interests made conversations cling to military history. He was entertained at a luncheon by Professor G.M. Wrong of the University of Toronto, and Sir Charles Fitzpatrick the Chief Justice. He also met the Canadian Prime Minister, Sir Wilfred Laurier, and his Conservative opponent Robert Borden, and heard them speak.

Chance seating at dinner placed him alongside a Mr. Mackenzie King whom the Governor-General thought "the coming man." He was, wrote Corbett, "deputy minister of Labour a young clean-shaven man of thickset Canadian type," who told Corbett of how he had stopped Japanese fishing vessels being issued licenses wholesale for fishing on the West Coast by threatening to denounce the Anglo-Japanese treaty. ${ }^{27}$

The most pronounced Canadian viewpoint that Corbett encountered was put forward with no lack of self-confidence by that Toronto stalwart Colonel George Denison. ${ }^{28}$ It was, he explained, the United Empire Loyalists, and not the British nation at home, who were responsible for the birth of the Empire and who gave it a special character and flavour. They were worth supporting. On the other side of the coin, he introduced his Pantheon of useless peoples, who included the French, the Americans and the Australians - for the latter he expressed contempt. Corbett found these exclusivist views somewhat rigorous. ${ }^{29}$ Corbett met a few Canadian women at the social functions. Escape from them was one of his more congenial occupations during the Quebec stay. The Mayor of Toronto seems to have assigned himself to Corbett during the reception for the Prince of Wales at the Chateau Frontenac, which dominated the English-Canadian social life of the Quebec scene. The Mayor was "a fat rather brutal aggressive type of self-made city man" who was openly contemptuous of everything French and indeed everything complex. The Mayor "prided himself" on his democratic character. Yet he naively confessed how Lord Grey had won his heart at their first meeting by asking him to give him a light from his cigar, as Lord Grey's had gone out. "He quite took charge of me, explaining who everybody was and hustled me to the terrace afterwards with one of his great stalwart arms round my waist and the other round his homely little charwoman of a wife." $" 30$

In short, it must be said that Corbett found in both the social situation in Canada, and the arrangements made for the grandstanding of the events, insufficient protection from the shirt-sleeved ${ }^{31}$ democracy about which he showed little curiosity, and for which

26 Lt. Gen. Sir Percy H.N. Lake, Inspector General and Militia Council Member in Canada. Admiral Sir Charles Edmond Kingsmill, R.N.; newly appointed Director of the Naval Service of Canada. He was knighted in 1918.

27 Corbett Diary 20.VII.08.

28 Canadian Military writer of international stature.

29 Corbett Diary 17.VII.08.

30 Corbett to E.R.C. 24.VII.08; CP B/10.

31 He used this description and also "riff-raff" Corbett to E.R.C. 24.VII.08; CP B/10. 
he felt a distinct aversion. He was told that better educated English immigrants generally became "the leading men." 32

He did, however, record his impressions of the French Canadians. To put his remarks in perspective, two things must be mentioned. First, that he seems to have formed no impressions as a result of direct contact with people, but rather from English and English-Canadian impressions of them. Second, that it is only incidentally, and largely by conscious reference to the Pageant itself, that Corbett showed any understanding of the fact that this whole pompous affair was meant to celebrate the French origins of Canada. It is true that the Governor General personally informed Corbett that his idea in promoting the whole thing was to encourage and develop rapport between the French and English sections of the population of Canada, together with dedication to the concept of Empire - the latter of which was played down in the original arrangements. He had, he said, found the French cold, and "sulky" towards his idea in the beginning, and it is clear that they were cajoled and dragged by turns to this brotherhood occasion. $^{33}$

It is also true that Sir Wilfrid Laurier cut a picturesque figure in the gathering, that the Premier of Ontario "made handsome advances to the French," 34 that post-prandial speeches evoked the required responses, and that the main part of the pageant did depict seventeenth century French Canadian history. What is unmistakable in Corbett's account, as well as in the later account of the pageant, published in French ${ }^{35}$ when all was over, is that there were, in reality, two celebrations taking place at Quebec in July 1908. On the one hand, there was a French Canadian celebration of their own past, called forth by English pressure, and tolerated rather than absorbed by the Anglo-Saxons in the interests of national and imperial unity. On the other, was a group of Anglo-Saxons who could tolerate the French nature of the gathering by virtue of the social opportunities it offered, and the sense of power to which such things as the anchored vessels of the Royal Navy gave rise. That military presence, the person of Lord Roberts, the review of the troops on the Plains of Abraham - all betokened a totally different interest; interest in the conquest of 1759. Corbett himself was a personal embodiment of this interest. Between these two groups the contacts were private and superficial as they played out their allotted roles. Just the right touch of irony was occasioned by the fact that British strength, mainly visible in the anchored fleet, represented to the two groups of Canadians present, French and English, protection against each other, although in different ways. It would be hard to find a better example of the real "Imperial factor" in Canadian history.

To his wife Corbett wrote his views on French Canada. He noted the attempt by the British Government to influence events by sending out the Duke of Norfolk to "see what influence he can bring to bear on the priests to water down their hostility to Canada and the English." One of the Duke's chief duties was to make a call on the famous

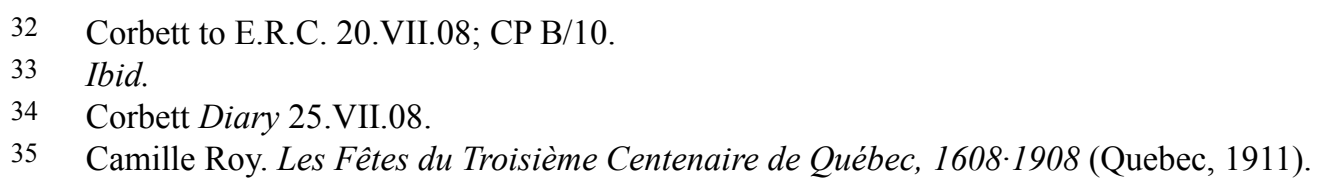


Catholic shrine at St. Anne de Beaupré. Corbett had been there the day before the Duke's visit, where, to his vast amusement, he found a Redemptrist monk, who had been born in Lancashire, "explaining the almost comic miracles with child-like correctness in his American twang." When the Duke was shown around, the whole miracle aspect was not mentioned. ${ }^{36}$ Corbett, of course, did not find this religious atmosphere congenial, but he noted that their own brand of Catholicism was important to the Quebecois as a native religion, for he discovered that the hatred felt by the French for Irish Catholicism was pronounced.

Corbett thought French-Canadians a narcissistic people whose attitudes to other people and political ideas were distinguished by degrees of hatred and suspicion. They were not, of course, intrinsically "loyal" to a British monarch, but they felt safe under that mantle to ignore the details of imperial policy, and yet to huddle there in safety against the pressures of the Americans, Irish-Canadians and English Canadians whom they disliked in that descending order of priority. ${ }^{37}$ His final crushing, but revealing, opinion was that they "remind me very much of the Irish with their vague longing for nationality and their lack of the qualities and energy by which alone it can be gained." 38

Corbett carried out his instructions concerning the attitude of Canada towards naval defence. On 21 July he had a long talk with Admiral Kingsmill, with regard to the formation of a Canadian marine force. Kingsmill was very pessimistic and his pessimism was derived from two opinions. One was that the reservoir of, and facilities for, turning out competent officers were limited, and unhappily they were only available from the Lower Deck. There was a "total absence of any sense of discipline," and he supposed this impossible to inculcate without a fixed service system. The other discouraging feature was the prevalence of political patronage that was bound to frustrate the sound building of an officer corps. Concretely, he proposed introducing some permanence into the service, employing personnel for at least a three year period, and taking the climate into consideration by employing the hands in the dockyard in the winter. But he was clearly not hopeful and "seemed to feel all this (was) only a poor substitute for money contributions to the Royal Navy." ${ }^{39}$

The Governor General was even more discouraging. Corbett asked him "how Canadian opinion stood with regard to a navy." Earl Grey said there was none. In his view the country was absorbed in perfecting its communications system in order to bring Far Eastern trade through the land, and, on that basis, to increase the population. Under these circumstances it was no use to try to force them into a more congenial Imperial posture. It was "no good forcing them - they won't spend money on a naval force." The Admiralty had no intention of attempting to do that, said Corbett. They only wanted to work with the material at hand; indeed they would have no confidence in any force that did not have the "heart of the country behind it." Again the Governor General reported that nothing must be expected, and asked that the matter be allowed to sleep as

36 Corbett to E.R.C. 20.VII.08; CP B/10.

37 Corbett to E.R.C. 24.VII.08; CP B/10.

38 Ibid.

39 Corbett Diary 15.VII.08. 
the Canadians needed time to acquire the strength necessary to a proper defence arrangement. Grey pointed out further that any active measures of defence, especially in the Great Lakes, would certainly alarm the Americans, who might easily give six months notice and denounce the treaty neutralizing the inland waters. Corbett pressed him to say whether any Canadian naval force would weaken Canada's position with regard to the United States. The answer was yes. Pressed further to state whether a militia might not be prepared on the coast and thus avoid "arousing U.S.A. Suspicions," he "would not say anything and became thoughtful." Grey concluded the interview by remarking that the British authorities would do well to be content with the militia system, as it trained more Canadian "boys to arms." 40

General Lake, the British officer commanding in Canada, to whom Corbett talked for two hours on the day before he sailed, was more optimistic. Corbett referred to him as "a fine fellow with broad and clear views - [the] best authority by far on Canadian defence that I have met." Lake stated that the local navy or naval militia was not nearly as hopeless as the Governor General thought, but the ministers were corrupt. This, in his opinion, was sufficient reason for delaying a bill that had already existed in draft for three years, till after the next general election. He was also emphatic that any hint to Canadian ministers that the militia proposal would "be satisfactory to England would do no good."

Lake wanted a torpedo flotilla, and he already had plans complete for moving it by rail to the Great Lakes when it was needed. Indeed he appreciated Corbett's interest in the defence of the Great Lakes, and provided him with the secret and surprising information that war plans in case of war with the U.S.A. had been worked out. The plans were carefully based on the principle of counter-attack so as to make sure that the Americans crossed the frontier first and could be called the aggressors. Lake revealed that in 1898, he and Captain Reginald Custance, RN, had reconnoitred the Lake coasts of Erie and Ontario. No records of their reports existed in Canada, however, all copies having been destroyed. This was "done in 1898." Lake said he was willing to share his information with Slade and that correspondence about it could go in letters marked personal and travel in the Governor General's bag. Another good feature was that the Canadians had the bulk of the shipping on Lake Ontario, also that there were a number of 4.7 guns stored with ammunition at Toronto. Finally, Lake referred Corbett and Slade to General Sir J. Carmichael Smyth's report to Wellington on Canadian defence written during the war of 1812, and C.P. Lucas's comments thereon, and indicated that this represented the background to Lake's defence thinking on this subject. ${ }^{41}$

When he arrived home, Corbett passed this amalgam of information on to Slade, leaning most heavily on General Lake's optimism. Slade's reply again revealed the split in Admiralty opinion on Canadian defence. There was also the implicit principle of seeking Canadian defence help and yet concealing both its purpose and its general arrangements from Canadian ministers. It is worth quoting in full.

40 Note on Conversation with Earl Grey, Naval Intelligence Report. CP B/10.

41 Corbett Diary 28.VII.08. 
Many thanks for your most interesting letter. It is very much as I thought, but I did not think that the corruption was as bad as it is. It makes it very hard to do anything for them, and to a certain extent justifies Sir John's [Fisher's] attitude. For all that, we cannot give up. Canada is a part of the Empire, and however bad they may be it would be the most fatal policy on our part to even hint that in time of danger we would abandon any part of it. It would be the signal for a general disruption and all we should be left with would be the smaller colonies and India. Lord Crewe is very firm about the necessity of keeping our end up in Canada. I had another talk with Sir John about it a short time ago, and he got quite heated on the subject. The fear of making any move because it may arouse the Americans to make further exertion, is I think a very weak argument. If it holds good in North America why should we spend money on our armaments in this country, for we only excite the European nations to try and outbuild us and so bring about still further increased expenses.

I am extremely against the policy of the "big drum" which so many people like - but a great deal can be done in an unostentatious way which will go far to strengthen our position out there. As I think I have said before, anything which makes American operations in Canada difficult tends to keep them quiet, while the opposite policy is only to dangle a bait in front of them.

I will certainly write to General Lake as soon as I get back, and get what information I can out of him before he leaves. I am sorry he is going, as he is a very good man. ${ }^{42}$

In view of the forthcoming great excitement in Canada regarding the formation of a Canadian naval force this correspondence is revealing of British thought. It reinforces the notion that Sir John Fisher both deprecated the value of Canadian forces and understood the nature of Britain's relationship to America in a forthright way. What Slade meant by his "unostentatious" policy is not so clear. What is clear is that Canadian defence policy was held to be too important a matter for Canadians to be informed about it. It is also apparent that Canada's value in this connection was not intrinsic but rather for the effect on Imperial greatness if they were not properly defended - although how they could be mollified by what they were deliberately kept in ignorance of is not so clear. When the drum beat in 1914 Canada was not an important military power. Neither, however, did she prove to be a liability to Great Britain.

At all events after his conversations with General Lake, both the work Corbett had been commissioned to do, and the great gathering itself were virtually complete. After a final naval display of illuminations and fireworks it was time to go. The Prince of Wales in the Indomitable kept company with the original six ships as they passed up the river and through the Gulf in beautiful summer weather. Outside the Strait of Belleisle, the Prince's ship, to the strains of cheers and Auld Lang Syne; parted

42 Slade to Corbett 11.VII.08; CP B/10. 
company and sped home. Cold and fog dogged the squadron's track across the Atlantic, but the sun came out finally to welcome them back to Brerehaven on August seventh. On the 8th he had crossed Ireland and in the late afternoon took "tea in my nest again., 43

"So ended one of the best months I ever had" wrote the civilian sailor. ${ }^{44}$ 